\title{
PENGARUH PENGGUNAAN BAHAN AJAR PDM TERHADAP PRESTASI BELAJAR MAHASISWA PENDIDIKAN MATEMATIKA
}

\section{THE EFFECT OF THE USE OF PDM TEACHING MATERIALS ON MATHEMATICS EDUCATION STUDENT ACHIEVEMENT}

\author{
Nurmala $\mathbf{R}^{1)}$ \\ ${ }^{1}$ Jurusan Matematika, Fakultas Keguruan dan Ilmu Pendidikan, Universitas Borneo Tarakan \\ Jalan Amal Lama Nomor 1, Tarakan \\ Email: ${ }^{1}$ nurmala.r17@gmail.com
}

\begin{abstract}
ABSTRAK
Penelitian ini merupakan penelitian kuantitatif dengan metode Quasi eksperimen. Populasi dalam penelitian ini adalah mahasiswa jurusan pendidikan matematika FKIP Universitas Borneo Tarakan. Sampelnya adalah mahasiswa yang memprogramkan mata kuliah PDM yaitu kelas A1 dan kelas A2, dimana kelas A1 merupakan kelas eksperimen dan kelas A2 kelas kontrol. Tujuan penelitian adalah untuk mengetahui pengaruh penggunaan bahan ajar buku teks Pengantar Dasar Matematika terhadap prestasi belajar mahasiswa pendidikan matematika. Adapun teknik pengumpulan datanya adalah dengan menggunakan tes yaitu pretest dan posttest. Berdasarkan hasil penelitian menunjukkan bahwa rata-rata nilai pretest pada kelas eksperimen adalah 58,9 dan posttest 73,4 dan pada kelas kontrol ratarata nilai pretest adalah 59,5 dan pada posttest 64,4 . Hasil uji t menunjukkan bahwa sig. (2 tailed) $<0,05$ sehingga terlihat bahwa kelas ekperimen dengan menggunakan bahan ajar buku teks PDM memperoleh nilai rata-rata lebih tinggi dibandingkan kelas kontrol yang tidak menggunakan bahan ajar buku teks. Sehingga dapat disimpulkan bahwa penggunaan bahan ajar buku teks PDM memberikan pengaruh terhadap prestasi belajar mahasiswa pendidikan matematika FKIP UBT.
\end{abstract}

\section{Kata Kunci : Bahan Ajar; Prestasi Belajar; PDM}

\begin{abstract}
The research is a quantitative study using the Quasi experimental method. The population in this study were students majoring in mathematics education at the University of Borneo Tarakan FKIP. The sample is students who program PDM courses namely class A1 and class A2, where class $A 1$ is the experimental class and class $A 2$ the control class. The purpose of this study was to determine the effect of the use of teaching materials for introductory textbooks in Mathematics on student learning achievement in mathematics education. The data collection technique is to use tests that are pretest and posttest. Based on the results of the study showed that the average pretest value in the experimental class was 58.9 and 73.4 in the posttest and in the control class the average pretest value was 59.5 and 64.4 in the posttest. $T$ test results show that sig. ( 2 tailed) $<0.05$ so that it appears that the experimental class using PDM textbooks obtained an average value higher than the control class that did not use textbook teaching materials. So it can be concluded that the use of PDM textbook teaching materials has an influence on the learning achievement of mathematics education students of FKIP UBT.
\end{abstract}

Keywords: Teaching Material; Learning Achievement; PDM

\section{PENDAHULUAN}

Salah satu cara untuk membuat pembelajaran menjadi menyenangkan adalah dengan menggunakan bahan ajar yang menyenangkan pula, yaitu bahan ajar yang dapat membuat peserta didik 
merasa tertarik dan senang mempelajari bahan ajar tersebut. Dalam proses pembelajaran, bahan ajar berkedudukan sebagai modal awal yang akan digunakan atau diproses untuk mencapai hasil. Pengembangan bahan ajar memiliki beberapa fungsi diantaranya yaitu, sebagai pedoman bagi siswa terhadap kompetensi yang dikuasai, sebagai pedoman bagi guru untuk mengarahkan kegiatan pembelajaran dan sebagai alat evaluasi pembelajaran. Bahan ajar dapat dibuat dalam berbagai bentuk sesuai dengan karakteristrik materi ajar yang akan disajikan. Hernawan dkk (2012) mengatakan bahwa " bahan pembelajaran merupakan seperangkat materi atau subtansi pelajaran yang disusun secara runtut dan sistematis serta menampilkan sosok utuh dari kompetensi yang akan dikuasai peserta didik dalam kegiatan pembelajaran".

Pengembangan bahan ajar memiliki beberapa fungsi diantaranya yaitu sebagai pedoman bagi peserta didik terhadap capaian pembelajarn yang harus dikuasai, sebagai pedoman bagi pengajar untuk mengarahkan kegiatan pembelajaran, dan sebagai alat evaluasi pembelajaran. Fungsi bahan ajar bagi peserta didik yaitu sebagai pedoman terhadap kompetensi yang harus dikuasai. Melalui bahan ajar yang digunakan dalam pembelajaran, peserta didik dapat memahami materi dan konsep yang dipelajari dengan lebih mudah. Sedangkan fungsi dari bahan ajar bagi tenaga pendidik adalah sebagai pedoman dalam mengarahkan kegiatan pembelajaran.

Bahan ajar merupakan bagian penting dalam pelaksanaan pendidikan. Melalui bahan ajar pendidik akan lebih mudah dalam melaksanakan pembelajaran dan peserta didik akan lebih terbantu dan mudah dalam belajar. Bahan ajar dapat dibuat dalam berbagai bentuk sesuai dengan kebutuhan dan karakteristik materi ajar yang akan disajikan. Bentukbentuk bahan ajar dikelompokkan menjadi sebagai berikut : 1) Bahan ajar cetak (printed), yaitu sejumlah bahan yang disiapkan dalam kertas, yang dapat berfungsi untuk keperluan pembelajaran atau penyampaian informasi. Contoh: handout, buku, modul, lembar kerja siswa, brosur, leaflet, wall chart, foto/gambar, model, atau maket, 2) Bahan ajar dengar (audio) atau program audio, yaitu: semua sistem yang menggunakan sinyal radio secara langsung, yang dapat dimainkan atau didengar oleh seseorang atau sekelompok orang. Contoh: kaset, radio, piringan hitam, dan compact disk audio, 3) Bahan ajar pandang dengar (audio visual), yaitu: segala sesuatu yang memungkinkan sinyal audio dapat dikombinasikan dengan gambar bergerak secara sekuensial. Contoh: video, compact disk, dan film. 4) Bahan ajar interaktif (interactive teaching materials), yaitu: kombinasi dari dua atau lebih media (audio, teks, grafik, gambar, animasi, dan video) yang oleh penggunanya dimanipulasi atau diberi perlakuan untuk mengendalikan suatu perintah dan atau perilaku alami dari presentasi. Contoh: compact disk interaktif.

Buku teks merupakan bahan ajar berbentuk cetak yang dikembangkan sedemikian rupa memuat materi dan soalsoal latihan yang dapat dikerjakan oleh peserta didik. Buku teks dibuat semenarik mungkin agar peserta didik termotivasi dalam belajar sehingga peserta didik tidak perlu lagi bingung dalam mencari refrensi pembelajaran. Dan buku teks disesuaikan dengan capaian pembelajaran yang akan dicapai.

Prestasi belajar tidak dapat dipisahkan dari kegiatan belajar, karena belajar merupakan suatu proses, sedangkan prestasi belajar adalah hasil dari proses pembelajaran tersebut. Bagi seorang anak belajar merupakan suatu kewajiban. Berhasil atau tidaknya seorang anak dalam pendidikan tergantung pada proses belajar yang dialami oleh anak tersebut. Prestasi adalah hasil yang telah dicapai seseorang dalam melakukan kegiatan. Gagne (1985) menyatakan bahwa prestasi belajar dibedakan menjadi lima aspek, yaitu: kemampuan intelektual, strategi kognitif, informasi verbal, sikap dan keterampilan.

Setiap aktivitas yang dilakukan oleh seseorang tentu ada faktor yang mempengaruhinya, baik yang cenderung mendorong maupun menghambat. Demikian juga yang dialami dalam belajar. Ahmadi menyatakan ada beberapa faktor yang mempengaruhi 
prestasi belajar siswa, diantaranya faktor internal dan faktor eksternal. Factor internal meliputi factor dalam diri peserta didik, sedangkan factor eksternal adalah faktor diluar peserta didik yang meliputi dapat berupa sarana prasarana, situasi lingkungan baik itu lingkungan keluarga, sekolah maupun lingkungan masyarakat. Salah satu yang dapat meningkatkan prestasi belajar peserta didiki berkaitan dengan faktor eksternal adalah dengan menggunakan bahan ajar buku teks. Hal ini akan membantu peserta didik dalam memahami materi yang diajarkan dalam proses pembelajaran. Meningkatkan prestasi belajar, pengajar memiliki peranan yang sangat penting. Selain mengajar, dituntut memiliki kemampuan kreatifitas dalam membantu peserta didik dalam memahami dan menyerap informasi dalam proses pembelajaran. Salah satunya dengan mengajar dengan menggunakan bahan ajat buku teks.

Berdasarkan uraian diatas, maka peneliti tertarik untuk melihat pengaruh penggunaan bahan ajar PDM terhadap prestasi belajar mahasiswa jurusan pendidikan matematika FKIP Universitas Borneo Tarakan.

\section{METODE PENELITIAN}

Penelitian ini dilaksanakan di Jurusan Pendidikan Matematika FKIP Universitas Borneo Tarakan. Populasi penelitian adalah seluruh mahasiswa pendidikan matematika, sedangkan sampel penelitian adalah semua mahasiswa yang memprogramkan mata kuliah Pengantar Dasar Matematika dengan dua kelas yaitu kelas A! dan kelas A2. Penelitian ini merupakan penelitian kuantitatif yang data penelitiannya berupa angka-angka dan dianalisis menggunakan statistic. Metode yang digunakan dalam penelitian ini adalah metode Quasi Eksperimen. Adapun desain penelitian adalah equivalent control group design dengan melibatkan dua kelas yaitu kelas eksperimen yang menggunakan bahan ajar buku teks PDM dan kelas kontrol yang tidak menggunakan bahan ajar buku teks PDM.

\section{Tabel 1. Desain Penelitian Quasi Eksperimen}

\begin{tabular}{cccc}
\hline Kelompok & pretest & perlakuan & posttest \\
\hline Eksperimen & $\mathbf{O 1}$ & $\mathrm{X}$ & 02 \\
\hline Kontrol & $\mathbf{0 1}$ & $\mathrm{C}$ & $\mathbf{0 2}$ \\
\hline
\end{tabular}

Keterangan :

O1 : tes awal sebelum perlakuan pada kelas eksperimen dan kontrol

O2 : tes akhir pada kelas eksperimen dan kontrol

$\mathrm{X} \quad$ : Pembelajaran menggunakan bahan ajar buku teks

C : Pembelajaran tidak menggunakan bahan ajar buku teks

Instrument penelitian yaitu
menggunakan tes pretest dan posttest.
Analisis data dilakukan dengan
menggunakan uji asumsi prasyarat
terlebih dahulu yaitu uji normalitas dan uji

homogenitas. Selanjutnya dilakukan uji hipotesis statistic yaitu uji t independent dengan menggunakan program SPSS versi 16.0 dengan hipotesis uji $t$ :

$\mathrm{H}_{0} \quad$ : sig $\geq \alpha$ (tidak terdapat perbedaan antara kelas eksperimen dan kelas kontrol)

$\mathrm{H}_{1} \quad: \mathrm{sig} \leq \alpha$ (terdapat perbedaan antara kelas eksperimen dan kelas kontrol )

Dengan $\alpha=0,05$

\section{HASIL DAN PEMBAHASAN}

\section{Hasil}

Data yang digunakan dalam penelitian ini adalah tes yaitu prestest dan posttest mahasiswa. Data terssebut digunakan untuk mengukur prestasi belajar mahasiswa pada perkuliahan pengantar dasar matematika kelas A1 sebagai kelas eksperimen dan kelas A2 sebagai kelas control. Pada kelas ekperimen proses perkuliaha dilaksanakan dengan menggunakan bahan ajar buku teks PDM dan pada kelas control proses perkuliahan dilaksanakan tanpa menggunakan buku teks PDM. Berdasarkan hasil penelitian, diperoleh nilai pretest dan posttes pada kelas eksperimen dan kelas kontrol. Data 
yang diperoleh kemudian diuji normalitas, homogenitas dan uji-t. berdasarkan hasil analisis diperoleh data sebagai berikut :

a) Analisis hasil pretest dan posttest

Tabel 2. Hasil Analisis Pretest dan Postest pada Kelas Eksperimen dan Kontrol

\begin{tabular}{|l|c|c|c|c|c|c|}
\hline \multicolumn{1}{|c|}{ Kelas } & \multicolumn{3}{|c|}{ Pretest } & \multicolumn{3}{c|}{ Posttest } \\
\hline & ata-rata & $\begin{array}{c}\text { Nilai } \\
\text { Tertinggi }\end{array}$ & $\begin{array}{c}\text { Nilai } \\
\text { Terendah }\end{array}$ & $\begin{array}{c}\text { Rata- } \\
\text { rata }\end{array}$ & $\begin{array}{c}\text { Nilai } \\
\text { Tertinggi }\end{array}$ & $\begin{array}{c}\text { Nilai } \\
\text { Terendah }\end{array}$ \\
\hline Eksperimen & 58,9 & 72 & 50 & 73,4 & 90 & 61 \\
\hline Kontrol & 59,5 & 70 & 50 & 64,4 & 72 & 56 \\
\hline
\end{tabular}

Berdasarkan table diatas dapat dijelaskan bahwa nilai rata-rata pretest untuk kelas eksperimen lebih kecil dibandingkan dengan kelas kontrol yaitu 58,9 pada kelas eksperimen dan 59,5 pada kelas kontrol. Sedangkan untuk nilai rata-rata posttest pada kelas eksperimen lebih besar dibandingkan dengan kelas kontrol yaitu 73,4 untuk kelas eksperimen dan 64,4 untuk kelas kontrol. b) Analisis data

a. Uji Normalitas

$\mathrm{Uji}$ normalitas hipotesis menggunakan uji Kolmogorov smirnov dengan bantuan spss 16.0 .

Tabel 3. Hasil Uji Normalitas Nilai Pretest dan Posttest

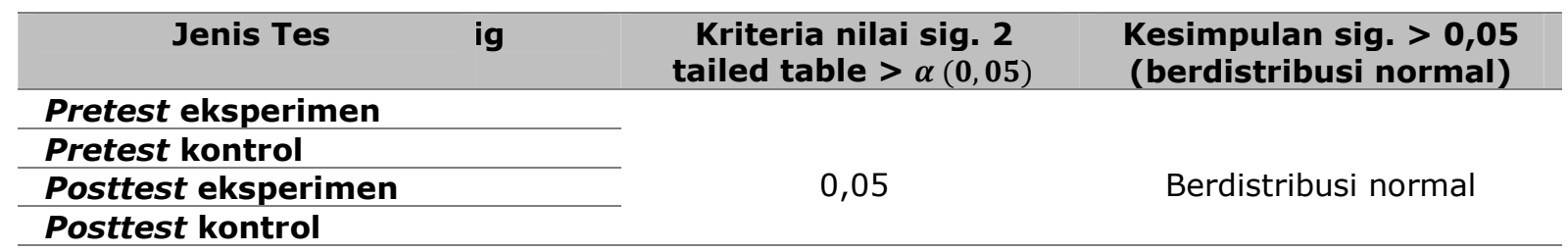

Berdasarkan hasil uji normalitas nilai pretest dan posttest hasil belajar mahasiswa diperoleh bahwa nilai pretst dan posttest kelas eksperimen maupun kelas control berdistribusi normal. Dari hasil data uji normalitas dengan nilai sig. 2 tailed $>\alpha(0,05)$, maka dapat diperoleh bahwa semua data berdistribusi normal sehingga dapat melanjutkan uji prasyarat selanjutnya yaitu uji homogenitas data. b. Uji Homogenitas

Uji homogenitas yang digunakan adalah test of homogeneity of variance. Tes ini digunakan untuk mengetahui kedua varian apakah memiliki karakteristik yang sama atau tidak.

Tabel 4. Hasil uji Homogenitas

\begin{tabular}{|c|c|c|}
\hline Jenis Tes & Sig & $\begin{array}{l}\text { kesimpulan sig. } \\
>0,05 \text { (homogen) }\end{array}$ \\
\hline Pretest eksperimen & 0,289 & \multirow{4}{*}{ Homogen } \\
\hline Pretest kontrol & 0,263 & \\
\hline Posttest eksperimen & 0,241 & \\
\hline Posttest kontrol & 0,296 & \\
\hline
\end{tabular}

Berdasarkan hasil uji homogenitas, diperoleh bahwa semua data nilai sig. > 0,05 sehingga dapat disimpulkan bahwa nilai pretest dan posttest pada kelas eksperimen dan kelas kontrol secara keseluruhan berasal dari data yang sama atau homogen. Setelah dilakukan uji prasyarat didapatkan bahwa uji normalitas dan uji homogenitas terpenuhi sehingga analisi dapat dilanjutkan 
pada pengujian hipotesis penelitian dengan menggunakan uji $t$ independent.

c. Uji t independent

Setelah uji prasyarat terpenuhi, maka dilanjutkan dengan $\mathrm{uji} \mathrm{t}$ independent untuk menguji hipotesis penelitian. Data hasil analisis yang diperoleh dari uji dengan menggunakan independent sample $t$ test dapat dilihat dalam table berikut :

Tabel 5. Uji t independent

\begin{tabular}{|l|l|c|l|c|}
\hline & \multicolumn{4}{|l|}{ Test for quality of mean } \\
\cline { 2 - 5 } & $\begin{array}{l}\text { Sig. } \\
(2 \text { tailed })\end{array}$ & $\begin{array}{l}\text { Mean } \\
\text { difference }\end{array}$ & $\begin{array}{l}\text { Standar } \\
\text { mean diffence }\end{array}$ \\
\hline $\begin{array}{l}\text { Bahan ajar } \\
\text { PDM terhadap } \\
\text { prestasi beajar }\end{array}$ & $\begin{array}{l}\text { Equal } \\
\text { variance } \\
\text { assumed }\end{array}$ & 0,00 & $-0,651$ & 1,413 \\
\hline
\end{tabular}

Berdasarkan analisis $u j i \quad t$ independent memperoleh hasil bahwa sig. (2.tailed) $<0,05$ maka $\mathrm{H}_{0}$ ditolak dan $\mathrm{H}_{1}$ diterima. Sehingga dapat disimpulkan bahwa nilai prestasi belajar mahasiswa pendidikan matematika menunjukkan perbedaan yang signifikan yaitu pembelajaran dengan menggunakan bahan ajar buku teks PDM mempengaruhi prestasi belajar mahasiswa.

\section{Pembahasan}

Penggunaan bahan ajar buku teks PDM memberikan pengaruh terhadap prestasi belajar mahasiswa pendidikan matematika. Selama proses pembelajaran dalam perkuliahan dengan menggunakan bahan ajar buku teks PDM pada kelas eksperimen berlangsung dengan efektif. Bahan ajar yang telah dikembangkan meliputi materi dan soal latihan yang membantu mahasiswa dalam memahami materi perkuliahan. Mahasiswa tidak lagi bingung ketika dalam kelas karena kurangnya refrensi yang digunakan. Dengan menggunakan bahan ajar buku teks PDM, mahasiswa dapat dengan mudah memahami materi yang disampaikan oleh dosen pengampu. Selain itu, soal-soal latihan yang ada dalam bahan ajar membantu mahasiswa juga dalam memahami permasalahan yang berkaitan dengan kehidupan sehari-hari.

Pembelajaran pada kelas kontrol dilaksanakan tanpa menggunakan bahan ajar buku teks PDM. Namun hanya mengandalkan refrensi seadanya yang dibawa oleh mahasiswa dalam perkuliahan. Bahkan terkadang mahasiswa tidak mempunyai refrensi sama sekali pada saat perkuliahan. Sehingga sangat terlihat perbedaan anatar kelas eksperimen yang menggunakan bahan ajar buku teks dengan kelas kontrol yang tidak menggunakan bahan ajar buku teks PDM.

Hasil pretest dan posttest yang telah diperoleh dari kelas eksperimen dan kelas kontrol mengalami perubahan. Pada pretest, kelas kontrol memiliki nilai ratarata yang lebih besar dari pada kelas eksperimen. Namun setelah diberikan perlakuan, rata-rata nilai pada kelas eksperimen lebih besar dibandingkan dengan kelas kontrol. Sehingga dapat dikatakan bahwa dengan menggunakan bahan ajar buku teks PDM berpengaruh terhadap prestasi belajar mahasiswa. Bahan ajar buku teks PDM dapat memberikan hasil yang maksimal dibandingan dengan tanpa menggunakan bahan ajar buku teks. Bahan ajar buku teks PDM dapat menarik perhatian mahasiswa dalam proses pembelajaran karena disusun secara sistematis dengan bahasa yang sederhana.

Selain itu, hasil analisis data penelitian diperoleh bahwa bahan ajar buku teks PDM dapat mempengaruhi prestasi belajar mahasiswa. Hal ini ditunjukkan dengan adanya perbedaan rata-rata skor posttest prestasi belajar pada kelompok eksperimen dan kelompok kontrol. Kelompok eksperimen lebih baik dari kelompok kontrol. Hal itu disebabkan oleh beberapa factor, diantaranya adalah kelompok eksperimen tertarika dengan bahan ajar yang disajikan karena 
JURNAL BORNEO SAINTEK

Volume 2, Nomor 2, Oktober 2019

e-ISSN 2599-3313

p-ISSN 2615-434X

sebelumnya tidak disediakan bahan ajar yang memadai ketika perkuliahan dimulai. Bahan ajar buku teks PDM disajikan dengan menarik dengan bahasa yang sederhana mudah difahami oleh mahasiswa sehingga mahasiswa termotivasi untuk belajar dalam mengerjakan soal-soal yang diberikan dalam perkuliahan.

\section{KESIMPULAN}

Berdasarkan analisis data dan pembahasan dalam penelitian ini dapat disimpulkan bahwa bahan ajar buku teks PDM dapat mempengaruhi prestasi belajar mahasiswa pendidikan matematika. Hal ini dpaat dibuktikan dengan hasil nilai ratarata posttest pada kelas eksperimen lebih tinggi daripada kelas kontrol. Dan berdasarkan hasil uji hipotesis diperoleh hasil sig. $\leq 0,05$ yang artinya $\mathrm{H}_{0}$ ditolak dan $\mathrm{H}_{1}$ diterima, artinya bahan ajar buku teks pada kelas eksperimen memberikan pengaruh yang signifikan terhadap prestasi belajar mahasiswa pendidikan matematika FKIP Universitas Borneo Tarakan.

\section{DAFTAR PUSTAKA}

Andi Prastowo.

(2011). Panduan Kreaktif Membuat Bahan Ajar Inovatif: Menciptakan Metode
Available online at www.jurnal.borneo.ac.id Halaman 19-24

Pembelajaran yang Menarik dan Menyengkan. Yogyakarta: Diva Press Arikunto, S. 2012. Dasar-dasar Evaluasi Pendidikan. Jakarta: Bumi Aksara.

Djamarah, Bahri. 2017. Prestasi belajar dan kompetensi guru. Jakarta : Usaha Nasional

Diknas. 2004. Pedoman Umum Pemilihan dan Pemanfaatan Bahan Ajar. Jakarta : Ditjen Dikdasmenum

Hernawan, Herry, dkk. 2012. Pengembangan Bahan Ajar. Handout

Mushlich, mansur. Hakikat dan fungsi buku teks. http://www.snurmuslich.blogspot.co $\mathrm{m} / 2008 / 10 / 04$ archive.html.hlm. 1, diakses 20 mei 2017

R, Nurmala dan Izzatin, Maharani. 2018. Pengembangan Bahan Ajar Perkuliahan PDM Berbasis Buku Teks Untuk Menumbuhkan Kemandirian Belajar Mahasiswa Pendidikan Matematika. Jurnal Borneo Saintek Vol 1 No 3 , Oktober 2018. e-ISSN 2599-3313, p-ISSN 2615-434X

Rusman. 2012. Model - model Pembelajaran. Jakarta: Raja Grafindo Persada

Sudjana. 2005. Metode Statistik. Bandung: Tarsito

Sugiyono. 2012. Metode Penelitian Pendidikan Pendekatan Kuantitatif, Kualitatif, dan R\&D. Bandung: Alfabeta 
